$$
\text { Conf - } 9406: 131--24
$$

DOE/MC/28053-94/C0367

\title{
THERMAL/CHEMICAL DEGRADATION OF INORGANIC MEMBRANE
} MATERIALS

\section{Authors:}

G. N. Krishnan , i

A. Sanjurjo

A. S. Damle

B. J. Wood

K.-H. Lau

\section{Contractor:}

SRI International

333 Ravenswood Avenue

Menlo Park, California 94025

\section{Contract Number:}

DE-AC21-92MC28053

\section{Conference Title:}

Coal-Fired Power Systems 94 -- Advances in IGCC and PFBC

Review Meeting

\section{Conference Location:}

Morgantown, West Virginia

\section{Conference Dates:}

June 21-23, 1994

\section{Conference Sponsor:}

U.S. Department of Energy, Office of Fossil Energy, Morgantown Energy Technology Center 


\section{DISCLAIMER}

This report was prepared as an account of work sponsored by an agency of the United States Government. Neither the United States Government nor any agency thereof, nor any of their employees, makes any warranty, express or implied, or assumes any legal liability or responsibility for the accuracy, completeness, or usefulness of any information, apparatus, product, or process disclosed, or represents that its use would not infringe privately owned rights. Reference herein to any specific commercial product, process, or service by trade name, trademark, manufacturer, or otherwise does not necessarily constitute or imply its endorsement, recommendation, or favoring by the United States Government or any agency thereof. The views and opinions of authors expressed herein do not necessarily state or reflect those of the United States Govermment or any agency thereof.

This report has been reproduced directly from the best available copy.

Available to DOE and DOE contractors from the Office of Scientific and Technical Information, 175 Oak Ridge Turnpike, Oak Ridge, TN 37831; prices available at (615) 576-8401.

Available to the public from the National Technical Information Service, U.S. Department of Commerce, 5285 Port Royal Road, Springfield, VA 22161; phone orders accepted at (703) 487-4650. 


\section{DISCLAIMER}

Portions of this document may be illegible in electronic image products. Images are produced from the best available original document. 
$9 b .6$

Thermal/Chemical Degradation of

Inorganic Membrane Materials

CONTRACT INFORMATION

Contract Number

Contractor

Contractor Proj. Mgr.

Principal Investigators

METC Project Manager

Period of Performance

Schedule and Milestones
DE-AC21-92MC28053

SRI International

333 Ravenswood Avenue

Menlo Park, CA 94025

(415) 326-6200

Gopala N. Krishnan

Gopala N. Krishnan

Angel Sanjurjo

Ashok S. Damle

Bernard J. Wood

Kai-Hung Lau

Venkat K. Venkataraman

August 24, 1992 to December 19, 1994

FY94 Program Schedule

\begin{tabular}{|l|c|c|c|c|c|c|c|c|c|c|c|c|c|}
\hline \multicolumn{1}{|c|}{ Task } & S & O & N & D & J & F & M & A & M & J & J & A & S \\
\hline Topical Report \&Test Plan Development & & & & & & & & & & & & & \\
\hline ExperimentalTesting & & & & & & & & & & \\
\hline
\end{tabular}

\section{OBJECTIVES}

The overall objective of this program is to evaluate the long-term thermal and chemical degradation of inorganic membranes that are being developed to separate gaseous products produced by the gasification or combustion of coal in fixed-, fluidized-, and entrained-bed gasifiers, direct coalfired turbines, and pressurized-fluidized-bed combustors. Specific objectives of this program are to (1) quantify the extent of the degradation process for the three most detrimental mechanisms by performing laboratory-scale experiments, and (2) develop a predictive model for membrane degradation under operating conditions.

\section{BACKGROUND INFORMATION}

Several impurities, such as $\mathrm{H}_{2} \mathrm{~S}, \mathrm{NH}_{3}, \mathrm{SO}_{2}$, $\mathrm{NO}_{x}$, and trace metal compounds are generated during the coal conversion process and they must be removed from the coal gas or the combustor flue gas to meet environmental standards. In an integrated-gasification combined-cycle plant, removal of such impurities from the gasifier product at high temperature increases the efficiency of electric power generation. Inorganic membranes are potentially attractive for such an application. They are also being considered as a means to separate from coal gas a high-value bulk component such as hydrogen. Hence, it is important to identify membrane materials that 
possess the required characteristics of permeability, selectivity, and durability for use at high temperatures in a severe gaseous environment.

\section{PROJECT DESCRIPTION}

To achieve the overall objective, the program is divided into the following tasks:

1. Development of evaluation methodology

2. Evaluation of potential long-term degradation mechanisms

3. Submission of a topical report and a plan for experimental testing

4. Experimental testing

5. Model development.

In Task 2 which has been completed, Krishnan, et. al. (1993) evaluated potential inorganic membrane degradation mechanisms based upon an extensive literature search and theoretical calculations. Thermal sintering, hydrothermal attack, reaction with ash components, attack by vapor and solid phase alkali compounds, and deposition of carbon from the gas phase were identified as the likely degradation mechanisms for ceramic and metallic membranes.

The topical report describing this work was submitted in March 1994. Experimental testing of candidate materials (Task 4) is currently in progress. Task 5 is a separate option that may be exercised by the U.S. Department of Energy at the conclusion of Task 4 .

\section{CANDIDATE MEMBRANE MATERIALS}

Micro-porous inorganic membranes, in which the separation process is based upon Knudsen diffusion, are available for commercial gas separation needs, but their selectivity is limited. A variety of developmental efforts are currently under way, many sponsored by U.S. Department of Energy (DOE), to improve the selectivity and flux characteristics of porous inorganic membranes (Liu, et. al., 1992; Goldsmith, et al., 1992; Gavalas, 1992; Yates, et. al., 1993). DOE is also sponsoring efforts to increase the applicability of metallic membranes (Edlund, 1993).
At present, no inorganic membranes are commercially available for application in the hightemperature, high-pressure (HTHP) gas environments encountered in integrated gasification combined cycle (IGCC), pressurized fluidized bed combustion (PFBC), and direct coal fired turbine (DCFT) applications. Most of the inorganic membrane developmental efforts have focused on hydrogen separation membranes which may be used in an IGCC system for maximizing hydrogen production from coal gas or to remove $\mathrm{H}_{2} \mathrm{~S}$ and $\mathrm{NH}_{3}$ contaminants via thermal or catalytic decomposition of these contaminants.

The candidate inorganic membranes may be grouped as follows:

1) Dense Metallic Membranes. Both palladium and platinum membranes have been investigated for their hydrogen separation ability. Developmental work is presently underway to increase their tolerance to high temperature as well as sulfur species by combining platinum and palladium metal layers with base metal and barrier oxide layers.

2) Silica Based Membranes. Micro-porous silica/glass membranes have been commercially available with pore sizes down to $40 \AA$ (e.g., Vycor glass). Efforts are underway to reduce the pore size of such membranes by CVD techniques.

3) Alumina Based Membranes. Micro-porous gamma alumina/alpha alumina composite membranes are commercially available with pore sizes down to $40 \AA$ (e.g., membralox membranes). Efforts are underway to reduce the pore size of the alumina membranes by depositing additional nanopore layers.

4) Carbon Based Membranes - Carbon molecular sieves (CMS) have been extensively used in the chemical industry for gas separation applications. Efforts are presently underway to develop carbon/ carbon composite CMS membranes, where a top layer of CMS is deposited on a porous carbon support.

\section{EXPERIMENTAL · TESTING}

Three approaches are being used to evaluate the degradation of the membrane materials: (1) exposure of membrane materials to simulated coal gas streams under well-defined conditions, followed by characterization of the changes that 
occur in their physical and chemical properties, (2) long-term testing of the permeation performance of membranes under representative conditions, and (3) exposure of the membrane materials to the hot coal gas stream of an operating coal gasifier, followed by examination and evaluation of durability.

\section{RESULTS}

\section{Exposure Studies}

The purpose of the exposure tests is to determine the changes in physical characteristics, chemical composition, and pore size distribution of the membrane materials as a result of exposure to simulated IGCC coal gas environments.

Figure 1 shows a schematic of the exposure test apparatus. For atmospheric pressure tests at temperatures up to $1000^{\circ} \mathrm{C}$, a quartz exposure tube enclosed in a furnace is used. A movable quartz rack/platform, within the tube allows convenient placement of membrane samples. The desired gaseous environment is generated by mixing appropriate dry gases and adding steam and alkali vapors supplied from separate generation systems. The exhaust gas from the exposure tube is vented through a condenser into a fume hood. and a back pressure regulator which controls the exposure environment pressure to a desired level.

A similar apparatus has been constructed for experiments at elevated pressure. The exposure tube is made of an alloy steel and is equipped with flanged ends. Constant pressure is maintained in the tube by means of a back pressure regulator in the effluent stream.

To date, commercially available Vycor glass and $\gamma$-alumina membranes have been tested, in addition to platinum and palladium metal foils. The samples were exposed for various periods $(24,76$, and 113 hours) to two coal gas compositions, at three temperatures $\left(1000,800\right.$, and $\left.650^{\circ} \mathrm{C}\right)$, in separate, atmospheric-pressure experiments. The two gas compositions represent extremes in gasifier type. The gas simulating a fixed-bed, airblown gasifier product contained $18 \% \mathrm{H}_{2}, 9 \% \mathrm{CO}$, $12 \% \mathrm{CO}_{2}, 1 \% \mathrm{H}_{2} \mathrm{~S}, 30 \% \mathrm{H}_{2} \mathrm{O}$ and $30 \% \mathrm{~N}_{2}$, whereas that from an entrained-bed, oxygen-blown gasifier contains $30 \% \mathrm{H}_{2}, 10 \% \mathrm{CO}_{2}, 0.5 \% \mathrm{H}_{2} \mathrm{~S}$, $15 \% \mathrm{H}_{2} \mathrm{O}$ and $44.5 \% \mathrm{CO}$.
The exposed membrane samples were analyzed by various techniques to determine changes in the physical and chemical characteristics of the membrane materials. The results are described below for each of the membrane materials.

Surface areas and average pore diameters of Vycor membrane samples were determined by the B.E.T. gas adsorption method. The results are summarized in Table 1. The surface area of Vycor decreased from a high of $188 \mathrm{~m}^{2} / \mathrm{g}$ for an unexposed sample to a low of $1.9 \mathrm{~m}^{2} / \mathrm{g}$ for a sample exposed for $24 \mathrm{~h}$ at $1000^{\circ} \mathrm{C}$. Mean pore size increased from $4.1 \mathrm{~nm}$ to $11.7 \mathrm{~nm}$ after $76 \mathrm{~h}$ exposure at $800^{\circ} \mathrm{C}$, but after $24 \mathrm{~h}$ exposure at $1000^{\circ} \mathrm{C}$, all microporosity was lost.

$\mathrm{X}$-ray diffraction was used to determine changes in the crystallinity of the exposed membrane samples. The unexposed Vycor membrane sample, which was transparent, was found to be completely amorphous. After exposure at $800^{\circ} \mathrm{C}$, the sample turned opaque and developed a crystalline cristobalite phase. The sample exposed to $1000^{\circ} \mathrm{C}$ appeared fufsed and completely crystallized. Thus, temperatures greater than $650^{\circ} \mathrm{C}$ in the coal gas environment are found to be detrimental to the silica based membranes. These results are significant also for modifiied membranes based on the addition of silica layers to commercial Vycor and alumina membranes.

\section{Table 1. Changes in Vycor Membrane Properties with Temperature}

\begin{tabular}{||l|c|c||}
\hline \multicolumn{1}{|c|}{$\begin{array}{c}\text { Membrane } \\
\text { Sample }\end{array}$} & $\begin{array}{c}\text { BET Surface } \\
\text { Area (m²/gm) }\end{array}$ & $\begin{array}{c}\text { Mean Pore } \\
\text { Diameter (nm) }\end{array}$ \\
\hline Unexposed & 188 & 4.1 \\
\hline $\begin{array}{l}\text { Exposed at } 650^{\circ} \mathrm{C} \\
\text { for } 113 \mathrm{hrs}\end{array}$ & 140 & 4.5 \\
\hline $\begin{array}{l}\text { Exposed at } 800^{\circ} \mathrm{C} \\
\text { for } 76 \mathrm{hrs}\end{array}$ & 33 & 11.7 \\
\hline $\begin{array}{l}\text { Exposed at } \\
1000^{\circ} \mathrm{C} \text { for } 24 \mathrm{hrs}\end{array}$ & 1.9 & --- \\
\hline
\end{tabular}




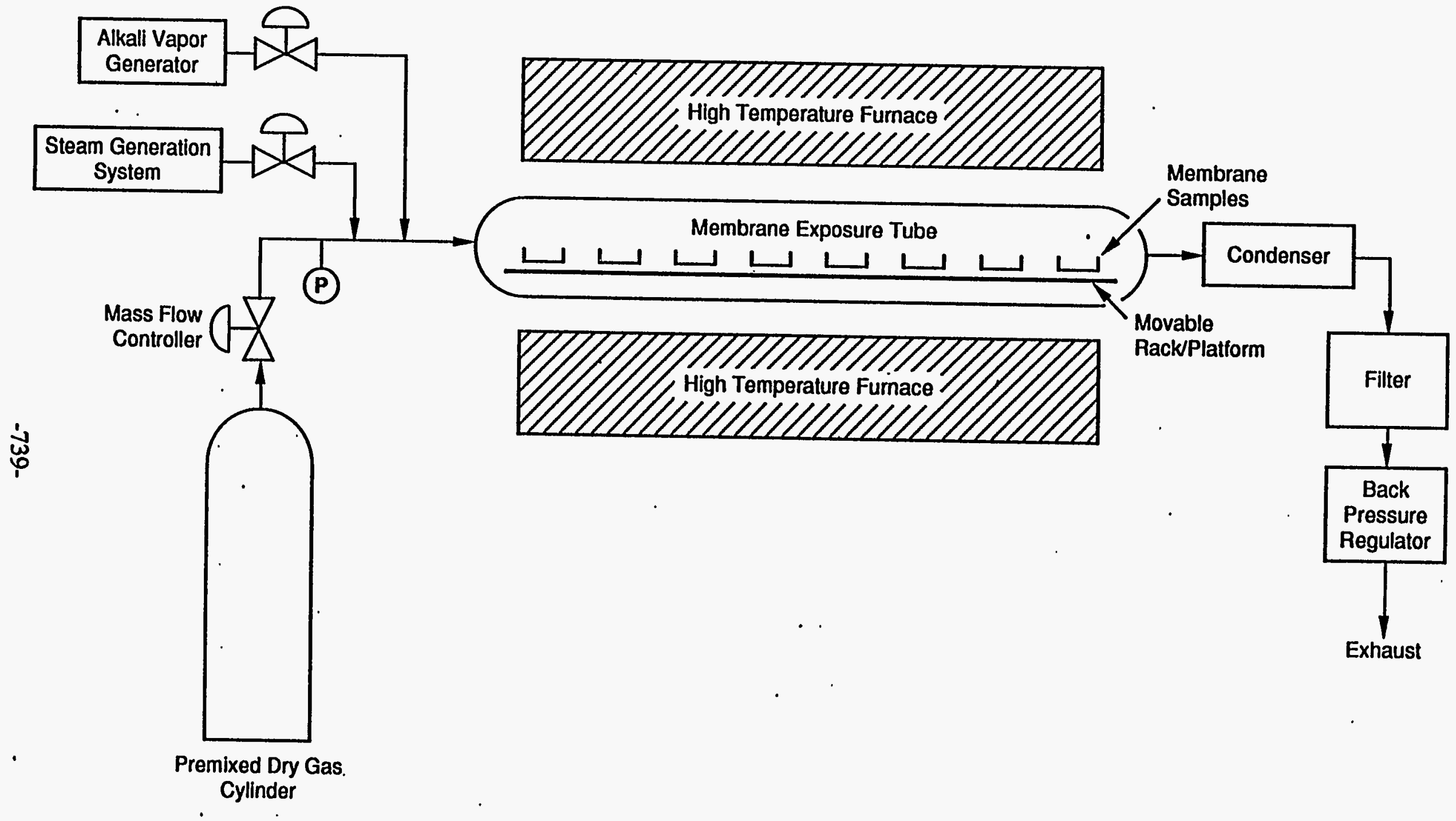

Figure 1. Schematic Diagram of the Reactor for Membrane Exposure Tests 
The gamma-alumina membrane samples were also analyzed by X-ray diffraction (XRD) as well as by B.E.T. XRD identified $\alpha$-alumina as the dominant bulk phase in the samples, but it failed to detect the $\gamma$-alumina phase present in the surface layers that is critical to the permselective character of the membrane. Refinement of this technique is necessary to determine the phase change in the thin - $\gamma$-alumina layer due to high-temperature coal gas exposure. If phase changes in the surface layers occur, they would likely cause pore coarsening.

Nitrogen B.E.T. analysis of the alumina membranes indicated that a significant decrease in surface area occurred during exposure at all the temperatures studied (Table 2). The surface area of an unexposed sample was about $2.1 \mathrm{~m}^{2} / \mathrm{g}$.

Exposure for $114 \mathrm{~h}$ at $650^{\circ} \mathrm{C}$ decreased the surface area to $0.9 \mathrm{~m}^{2} / \mathrm{g}$, and $76 \mathrm{~h}$ at $800^{\circ} \mathrm{C}$ reduced the surface area to $0.4 \mathrm{~m}^{2} / \mathrm{g}$. Exposure for $24 \mathrm{~h}$ at $1000^{\circ} \mathrm{C}$ decreased the surface area to $1.3 \mathrm{~m}^{2} / \mathrm{g}$. Because of these low values of surface area, these samples are being reanalyzed with an alternative adsorbent gas (krypton) to obtain greater accuracy. Both the exposure duration and temperature appear to affect the surface area reduction by mechanisms such as sintering and phase transformation.

Table 2. Surface Area Changes of an Alumina Membrane as a function of Temperature.

\begin{tabular}{||l|c|}
\hline \multicolumn{1}{|c|}{ Test Conditions } & $\begin{array}{c}\text { BET Surface } \\
\text { Area (m } 2 / \mathrm{g})\end{array}$ \\
\hline Unexposed & 2.1 \\
\hline Exposed at $650^{\circ} \mathrm{C}$ for $113 \mathrm{hrs}$ & 0.9 \\
\hline Exposed at $800^{\circ} \mathrm{C}$ for $76 \mathrm{hrs}$ & 0.4 \\
\hline Exposed at $1000^{\circ} \mathrm{C}$ for $24 \mathrm{hrs}$ & 1.3 \\
\hline
\end{tabular}

During exposure of the $\gamma$-alumina membrane samples at 800 and $1000^{\circ} \mathrm{C}$, vaporization of trace contaminants in the material occurred. Such vapor species reacted with silica material present in the exposure reactor causing them to crystallize. This vaporization behavior was studied by high temperature mass spectrometry, and the vapors were found to be $\mathrm{CO}_{2}, \mathrm{H}_{2} \mathrm{O}, \mathrm{Na}(\mathrm{g})$, and $\mathrm{Zn}(\mathrm{g})$. Sodium vapor is detrimental to the operation of gas turbine components. Partial pressures of the $N$ and $\mathrm{Zn}$ vapor species over a membrane sample are given in Table 3. In this experiment, the sample was heated slowly from room temperature. $\mathrm{CO}_{2}$ evolution was observed at all temperatures whereas that of steam disappeared by $480^{\circ} \mathrm{C}$. Significant evolution of elemental $\mathrm{Na}$ and $\mathrm{Zn}$ began at $480^{\circ}$ and $1025^{\circ} \mathrm{C}$ respectively. The partial pressures of both species increased with temperatures. Sodium partial pressures were especially significant for coal gas exposure at 800 and $1000^{\circ} \mathrm{C}$.

Table 3. Partial Pressure of Gaseous Species Evolved from an Alumina Membrane

\begin{tabular}{||c|c|c||}
\hline & \multicolumn{2}{|c|}{ Partial Pressure (atm) } \\
\hline Temperature (C) & Na Species & Zn Species \\
\hline 480 & $3.05 \mathrm{E}-10$ & $<1 \mathrm{E}-10$ \\
\hline 545 & $1.15 \mathrm{E}-09$ & $<1 \mathrm{E}-10$ \\
\hline 675 & $7.18 \mathrm{E}-09$ & $<1 \mathrm{E}-10$ \\
\hline 780 & $3.25 \mathrm{E}-07$ & $<1 \mathrm{E}-10$ \\
\hline 850 & $1.44 \mathrm{E}-06$ & $4.71 \mathrm{E}-10$ \\
\hline 920 & $2.09 \mathrm{E}-06$ & $5.52 \mathrm{E}-09$ \\
\hline 1025 & $1.20 \mathrm{E}-06$ & $7.26 \mathrm{E}-09$ \\
\hline
\end{tabular}

Palladium foils exposed at $800^{\circ}$ and $1000^{\circ} \mathrm{C}$ melted, presumably due to formation of PdS. Analysis of one of a resolidified sample by SEM/EDAX indicated bulk sulfidation of palladium. At $650^{\circ} \mathrm{C}$ the exposed Pd sample deformed extensively. This sample was also analyzed by Auger electron spectroscopy (AES) to determine the elemental sulfur content on its surface. Sulfur was not only a predominant component of the surface, but, upon depth profiling by argon bombardment, it was found at a high level within the bulk of the metal foil (Figure 2). 


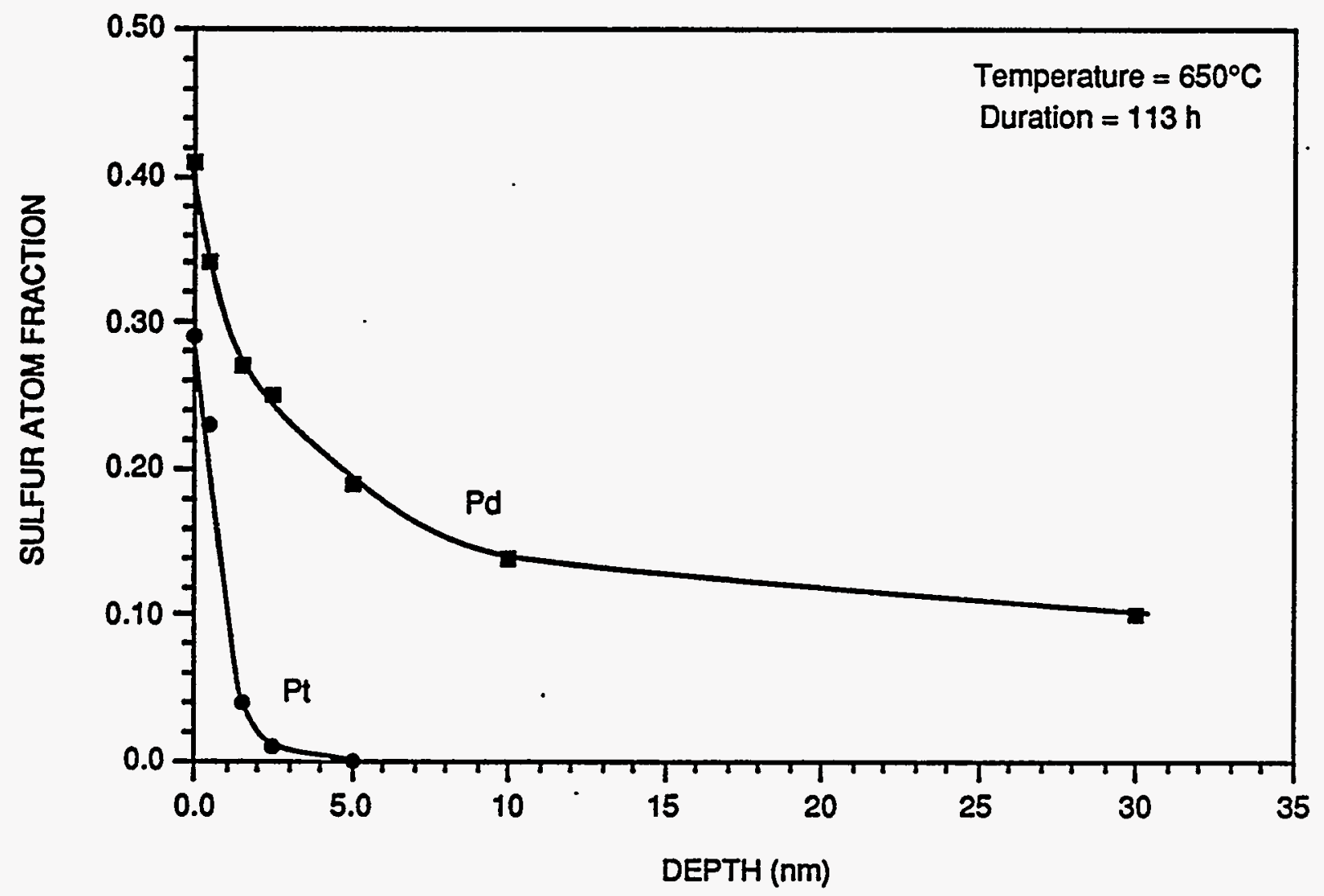

Figure 2. Incorporation of Sulfur on the Platinum and Palladium Membranes

Platinum foil samples exposed under all experimental conditions were unaffected visually. AES revealed a sulfur adlayer on the surfaces of all the samples, but the concentration decreased rapidly with argon sputtering and no sulfur was detected at depths about $5 \mathrm{~nm}$ beneath the foil surface. Thus, platinum sulfidation appears to be confined to the surface regardless of the exposure duration, temperature, and gas phase $\mathrm{H}_{2} \mathrm{~S}$ concentration.

\section{Long-Term Membrane Permeation Testing}

The purpose of long term testing of membrane permeation behavior is to quantify the changes in the membrane performance under controlled conditions. Specifically, changes in membrane permeation and selectivity characteristics will be determined as a function of time for a variety of operating conditions. The permeation measurements will also identify the key variables leading to loss of performance, if any, and will allow correlation of the observed degradation characteristics of the membrane materials with actual membrane performance under specified conditions of exposure.

Figure 3 is a schematic diagram of the test apparatus being assembled for long-term permeation testing. The system consists of mass flow controllers for mixing gases of known composition, a high temperature furnace, a gas chromatograph (GC), and a controlling computer that commands the GC and logs GC data. Steam will be supplied by using a high pressure pump to meter water into a vaporizer situated in the gas line. Alkali vapors will be generated in a high pressure vapor generation system similar to the one used in the exposure studies. 


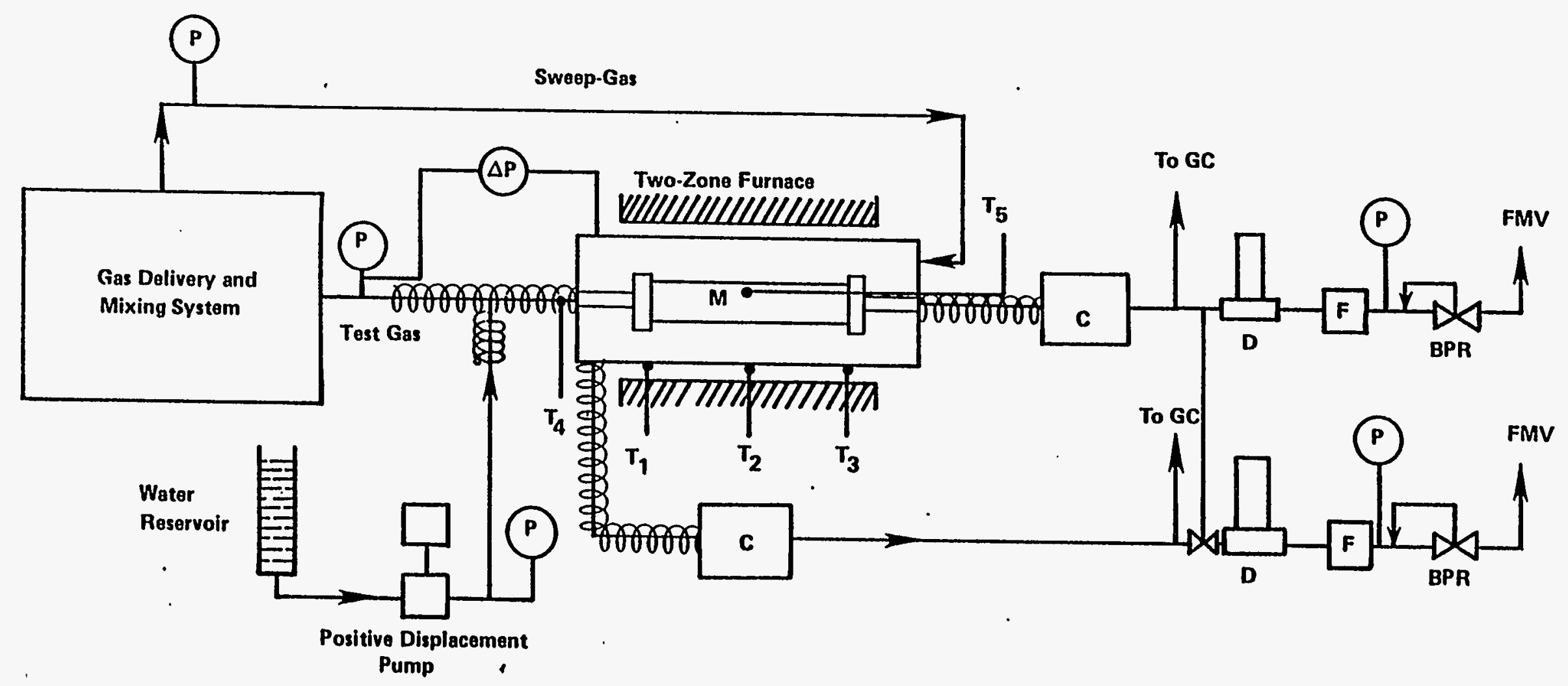

FMV: Flow Meter and Vent

M: Tubular Membrane Module

P: Pressure Gauge

$\triangle P: \quad$ Differential Pressure Gauge

$T_{1}-T_{6}:$ Temperature Measurement and Control

D: High Pressure Drier

BPR: Back Pressure Regulator

\author{
OOYO Preheater/Heated Lines \\ GC: Gas Chromatograph \\ C: Condensation and Liquid \\ Separation System
}

Figure 3. Schematic Diagram of the Membrane Test System 
The candidate membranes will be placed in appropriate membrane holders. The membranes will be exposed to typical gasifier product compositions on the feed side at realistic conditions of temperature and pressure. The flow rate and composition of the membrane feed gas, permeate gas, and feed reject gas will be monitored for an extended period of time, up to 60 days.

\section{FUTURE WORK}

Exposure studies will continue to determine changes in membrane characteristics in presence of fly ash and alkalis at high pressures, and for much longer durations. Modified Vycor and $\gamma$-alumina membrane samples will be included in these tests. Membrane permeation behavior will be determined in typical coal gas environments during long term tests. Also, selected membrane materials will be exposed to an actual hot coal gas stream at a pressurized fixed-bed gasifier facility, and the changes in the physical, chemical, and mechanical properties of the membrane that occur will be determined.

In Task 5, at the option of U.S. Department of Energy, the results from Task 4 and the data available in the literature will be used to develop a predictive model that can be used to estimate the long-term degradation of three selected inorganic membrane materials. Both theoretical and empirical approaches will be used in developing this model.

\section{REFERENCES}

Edlund, D. J., 1993. Catalytic Membranes for Facilitating the Water- Gas Shift Reaction. Proceedings of the Coal-Fired Power Systems 93 -- Advances in IGCC and PFBC Review Meeting, 233-237. DOE/METC-93/6131. NTIS/DE93000289. Springfield, Va.: National Technical Information Service.

Gavalas, G. 1992. Separation by Ceramic Membranes in Coal Gasification. Proceedings of the Twelfth Annual Gasification and Gas Stream Cleanup Contractors Review Meeting, 338-345. DOE/METC-92/6128. NTIS/DE93000229: Springfield, Va.: National Technical Information Service.

Goldsmith, R. L., R. J. Higgins, and B. A. Bishop. 1992. Low-Cost Ceramic Membranes and Supports for Gas Separation. Proceedings of the Twelfth Annual Gasification and Gas Stream Cleanup Contractors Review Meeting, 205-220. DOE/METC-92/6128. NTIS/DE93000229. Springfield, Va.: National Technical Information Service.

Krishnan, G. N., A. Sanjurjo, and B. J. Wood, 1993. Thermal/Chemical Degradation of Inorganic Membranes. Proceedings of the CoalFired Power Systems 93 -- Advances in IGCC and PFBC Review Meeting, 211-219. DOE/METC-93/6131. NTIS/DE93000289. Springfield, Va.: National Technical Information Service.

Liu, P. K. T., C. L. Lin, D. L. Flowers, J. C. S. Wu, and G. W. Smith. 1992. Gas Separations Using Ceramic Membranes. Proceedings of the Twelfth Annual Gasification and Gas Stream Cleanup Contractors Review Meeting, 351361. DOE/METC-92/6128. NTIS/DE93000229. Springfield, Va.: National Technical Information Service.

Yates, S. F., and A. X. Swamikannu, 1993. High Temperature Size Selective Membranes. Proceedings of the Coal-Fired Power Systems 93 -- Advances in IGCC and PFBC Review Meeting, 238-244. DOE/METC-93/6131. NTIS/DE93000289. Springfield, Va.: National - Technical Information Service. 